\title{
Fermentative profile and nutritive value of corn silage with Tamani guinea grass
}

\section{Perfil fermentativo e valor nutritivo de silagens de milho com capim-tamani}

\author{
Francielly Paludo ${ }^{1 *}$; Kátia Aparecida de Pinho Costa ${ }^{2}$; Mariana Borges de Castro \\ Dias $^{3}$; Fábio Adriano Santos e Silva ${ }^{3}$; Ana Carolina Gomes Silva ${ }^{4}$; Laíne Gonçalves \\ Rodrigues ${ }^{4}$; Sabryna Álex Almeida Silva ${ }^{4}$; Wender Ferreira Souza ${ }^{5}$; Ubirajara \\ Oliveira Bilego ${ }^{6}$; Mariane Porto Muniz ${ }^{7}$
}

\section{Highlights:}

Addition of Tamani guinea grass to corn silage decreased the DM and lactic acid.

Adding 40\% Tamani guinea grass to corn silage provided higher levels of crude protein and DIVMS.

Mixed silage is an alternative to improve the quality of exclusive corn silage.

\begin{abstract}
The use of silage has been an efficient alternative to feed supply during the shortage of roughage in dry periods, providing quality feed that is widely used in ruminant feeding. Thus, the objective of this study was to evaluate the fermentative characteristics and nutritive value of corn silage with Tamani guinea grass (Panicum maximum BRS cv. Tamani) through chemical composition, in vitro dry matter digestibility and protein fractionation. The experiment was conducted in a completely randomized design with four replications. The treatments consisted of five silages: corn; corn with $10 \%$ Tamani guinea grass; corn with 20\% Tamani guinea grass; corn with 30\% Tamani guinea grass; and corn with $40 \%$ Tamani guinea grass, totalling 20 experimental silos. The addition of tamani grass to silages was determined based on fresh matter. For ensiling, corn was harvested with $320 \mathrm{~g} \mathrm{~kg}^{-1} \mathrm{DM}$ (dry matter) and Tamani guinea grass in a 30-day development cycle with $286 \mathrm{~g} \mathrm{~kg}^{-1} \mathrm{DM}$. After 50 days of silage, the silos were opened to analyse the fermentative characteristics, chemical composition and protein fractionation of the silage. The results showed that the addition of Tamani guinea grass in corn silage increased the $\mathrm{pH}$ and buffering capacity and reduced the dry matter and lactic acid concentration but did not compromise the fermentative characteristics of silages. The addition of $40 \%$ Tamani guinea grass in corn silage provided increased levels of crude protein, in vitro dry matter digestibility, protein A, B1 and
\end{abstract}

1 M.e em Zootecnia, Instituto Federal Goiano, IF Goiano, Campus Rio Verde, IF Goiano, Rio Verde, GO, Brasil. E-mail: francielly. paludo@hotmail.com

2 Profa, Programa de Pós-Graduação em Ciências Agrárias/Agronomia e Zootecnia, IF Goiano, Campus Rio Verde, Rio Verde, GO, Brasil. E-mail: katia.costa@ifgoiano.edu.br

3 Discentes do Curso de Doutorado do Programa de Pós-Graduação em Ciências Agrárias/Agronomia, IF Goiano, Campus Rio Verde, Rio Verde, GO, Brasil. E-mail: maborges93.mb@gmail.com; fabioagro13@gmail.com

4 Discentes do Curso de Graduação em Zootecnia, IF Goiano, Campus Rio Verde, Rio Verde, GO, Brasil. E-mail: anacarolinagomes68@gmail.com; lainerodrigues16@gmail.com; sabrynarv@hotmail.com

5 Pós-Doutorando do Programa de Pós-Graduação em Zootecnia, IF Goiano, Campus Rio Verde, Rio Verde, GO, Brasil. E-mail: wenderzootecnia@hotmail.com

6 Pesquisador, Instituto de Ciência e Tecnologia COMIGO, ITC, Rio Verde, GO, Brasil. E-mail: ubirajarabilego@comigo.com.br

7 Discente do Curso de Mestrado do Programa de Pós-Graduação em Ciências Agrárias,/Agronomia, IF Goiano, Campus Rio Verde, Rio Verde, GO, Brasil. E-mail: mportomuniz@gmail.com

* Author for correspondence 
$\mathrm{C}$, and decreased the fractions $\mathrm{B} 3$ and $\mathrm{C}$, which makes Tamani guinea grass an alternative to improve the quality of exclusive corn silage, resulting in better quality silage.

Key words: Bromatological composition. Panicum maximum BRS cv. Tamani. Protein fraction. Zea mays.

\section{Resumo}

A utilização de silagens tem sido uma alternativa eficiente para suprir a escassez de volumoso no período seco, proporcionando alimento de qualidade, largamente utilizada na alimentação de ruminantes. Objetivou-se avaliar as características fermentativas, valor nutritivo, através da composição bromatológica digestibilidade in vitro da matéria seca e fracionamento de proteína da silagem de milho com capim-tamani (Panicum maximum BRS cv. Tamani). Foi utilizado delineamento experimental inteiramente casualizado, com quatro repetições. Os tratamentos foram constituídos de silagem: milho; milho com $10 \%$ de capim-tamani; milho com $20 \%$ de capim-tamani; milho com $30 \%$ de capim-tamani e milho com $40 \%$ de capim-tamani, totalizando 20 silos experimentais. A adição de capim-tamani na ensilagem foi calculada com base na matéria natural. Para a ensilagem, o milho foi colhido com 320 $\mathrm{g} \mathrm{kg}^{-1}$ de matéria seca (MS) e o capim-tamani no ciclo de desenvolvimento de 30 dias, com $286 \mathrm{~g}$ $\mathrm{kg}^{-1}$ MS. Após 50 dias da ensilagem, os silos foram abertos, para serem analisadas as características fermentativas, bromatológicas e fracionamento de proteína das silagens. Os resultados mostraram que adição do capim-tamani na ensilagem de milho aumentou o $\mathrm{pH}$, capacidade tampão e reduziu os teores de matéria seca e concentração de ácido lático, mas não comprometeu as características fermentativas da silagem. A adição de $40 \%$ do capim-tamani na ensilagem de milho proporcionou maiores teores de proteína bruta, digestibilidade in vitro da matéria seca e fração proteína $\mathrm{A}, \mathrm{B} 1$ e B e diminuiu a fração B3 e C, sendo alternativa para melhorar a qualidade da silagem exclusiva de milho.

Palavras-chave: Composição bromatológica. Fracionamento de proteína. Panicum maximum BRS cv. Tamani. Zea mays.

\section{Introduction}

Milk and beef productivity on pasture in Brazil is globally competitive. Although pastures are an important source of animal feed in the country, the seasonality of fodder plants implies low productive performance at certain times of the year. Therefore, using forage conservation methods such as silage is an interesting strategy to maintain efficient productive performance throughout the year (Santos, Fonseca, Sousa, Santos, \& Carvalho, 2020).

Of the recommended silage materials, corn crop is considered a reference because of its high energy content and favourable silage characteristics (Khan, Yu, Ali, Cone, \& Hendriks, 2015); it has high dry mass production per hectare and high energy values (Viana et al., 2012). As a result, silage corn cultivation has increased considerably around the world in recent years, becoming the main silage used in dairy cow diets (Khan, Tewoldebrhan, Zom, Cone, \& Hendriks, 2012).

The partial replacement of traditional corn silage by tropical forages has been of interest and is widely used in cattle feed, as these forages have advantages, such as high annual yield per area, perennity, low risk of loss and enhanced harvest flexibility (K. A. P. Costa et al., 2011). Thus, alternatives for silage production of annual crops with tropical forages have been emerging, either in the form of a consortium (Leonel et al., 2009; Ribeiro et al., 2017; Pariz et al., 2017; R. R. G. F. Costa et al., 2018; Souza et al., 2019; S. S. Oliveira et al., 2020) or with the addition of forage in the annual crop (Cruvinel et al., 2017).

In this context, corn silage with tropical forages can bring benefits, such as balancing the nutritional value, presenting improved qualitative 
characteristics in the dry matter, and providing increased nutrient production per area as well as flexibility of use, which is an important alternative in the off-season period. (Leonel et al., 2009; Pariz et al., 2017).

In addition to chemical composition, other ways to evaluate the quality of feed include evaluation of protein fractions, which are important in ruminant nutrition, because of the high impact on the production system, causing different gains in animal performance (Brandstetter et al., 2019).

However, studies evaluating the quality of corn silage with tropical forages are few. In the case of a new Panicum maximum cultivar, it is necessary to generate additional information on silage quality, which will enable its use as another alternative for ruminant feeding in the off-season.

Thus, the objective of this study was to evaluate the fermentative characteristics and nutritive value of corn silage with Tamani guinea grass (Panicum maximum BRS cv. Tamani) through chemical composition, in vitro dry matter digestibility and protein fractionation.

\section{Materials and Methods}

The experiment was carried out at the Federal Institute of Goias - Campus Rio Verde. Soil samples were collected at a $0-20 \mathrm{~cm}$ depth before the beginning of the experiment for physicochemical analysis. The soil of the experimental area was characterized as typical Dystrophic Red Latosol (H. G. Santos et al., 2018) and had the following characteristics: 450,200 , and $350 \mathrm{~g} \mathrm{~kg}^{-1}$ of clay, silt and sand contents, respectively; $\mathrm{pH}$ in $\mathrm{CaCl}_{2}: 6.0$; Ca: $2.8 \mathrm{cmol}_{\mathrm{c}} \mathrm{dm}^{-3} ; \mathrm{Mg}: 1.5 \mathrm{cmol}_{\mathrm{c}} \mathrm{dm}^{-3}$; $\mathrm{Al}: 0.02$ $\mathrm{cmol}_{\mathrm{c}} \mathrm{dm}^{-3} ; \mathrm{Al}+\mathrm{H}: 2.1 \mathrm{cmol}_{\mathrm{c}} \mathrm{dm}^{-3} ; \mathrm{K}: 0.57 \mathrm{cmol}_{\mathrm{c}}$ $\mathrm{dm}^{-3}$; CEC (cation exchange capacity): $6.97 \mathrm{cmol}_{\mathrm{c}}$ $\mathrm{dm}^{-3}$; P (Mehlich): $4.5 \mathrm{mg} \mathrm{dm}{ }^{-3}$; and OM: $29.3 \mathrm{~g}$ $\mathrm{kg}^{-1}$.

Corn seeds (hybrid 32R22) were sown $2 \mathrm{~cm}$ deep in rows spaced $50 \mathrm{~cm}$ apart. A total of $100 \mathrm{~kg} \mathrm{ha}^{-1}$ of $\mathrm{P}_{2} \mathrm{O}_{5}$ in the form of single superphosphate was applied at sowing. Corn plants were top-dressed with 150 and $75 \mathrm{~kg} \mathrm{ha}^{-1}$ of $\mathrm{N}$ and $\mathrm{K}_{2} \mathrm{O}$ in the form of urea and potassium chloride, respectively, at the stages of three and six fully developed leaves.

The plots were $14 \mathrm{~m}$ long and $6.5 \mathrm{~m}$ wide. The usable area of the plot was four centre rows, excluding $0.5 \mathrm{~m}$ extremities. Phytosanitary control was carried out with two applications of the insecticide Chlorfenapyr at $0.5 \mathrm{~L} \mathrm{ha}^{-1}$ using a backpack sprayer. Weeds were controlled through manual weeding.

A completely randomized design with four replicates was used. The treatments consisted of silage: corn; corn with 10\% Tamani guinea grass; corn with $20 \%$ Tamani guinea grass; corn with $30 \%$ Tamani guinea grass; and corn with $40 \%$ Tamani guinea grass, totalling 20 experimental silos. Tamani guinea grass was harvested from an experimental area of the Comigo Technological Institute, which was established in November 2017 and received nitrogen fertilization 30 days before cutting at a dose of $50 \mathrm{~kg}$ ha- $1 \mathrm{~N}$ at the source of urea in a sprinkler irrigation system.

For ensiling, corn was harvested with $320 \mathrm{~g} \mathrm{~kg}^{-1}$ dry matter (DM) and Tamani grass at the 30-day development cycle. Both crops were harvested at 20 $\mathrm{cm}$ above the soil level using a manual brush cutter. Subsequently, forages were chopped separately to approximately $10 \mathrm{~mm}$ of particle length using a stationary forage chopper.

The material was homogenized according to each level of Tamani guinea grass $(0,10,20,30$ and $40 \%$ based on fresh matter) and stored in experimental PVC tube silos measuring $10 \mathrm{~cm}$ in diameter and $40 \mathrm{~cm}$ in length. Subsequently, the material was compacted with an iron pendulum, and silos were closed with PVC lids and sealed with adhesive tape to prevent air exposure. The mean silage density was approximately $575.15 \pm 20.31 \mathrm{~kg} \mathrm{dm}^{-3}$. The experimental silos were stored in a covered area at room temperature. 
The fresh material (before ensiling) was analysed (Table 1) for dry matter (DM), crude protein (CP), lignin, ether extract (EE) and ash contents according to the methodologies described by the Official Methods of Analysis [AOAC] (1990). Neutral detergent fibre (NDF) and acid detergent fibre (ADF) were estimated by the method described by Mertens (2002). The content of total digestible nutrients (TDN) was calculated by the equation $(\% \mathrm{TDN}=105.2-0.68(\% \mathrm{NDF}))$, as proposed by Chandler (1990). The in vitro dry matter digestibility (IVDMD) was analysed using the technique described by Tilley and Terry (1963), which was adapted to the artificial rumen developed by $\mathrm{ANKOM}^{\circledR}$ (Daisy Incubator - in vitro true digestibility - IVTD).

\section{Table 1}

Chemical composition and protein fractionation of corn and Tamani guinea grass before ensiling (on a green basis)

\begin{tabular}{|c|c|c|}
\hline Chemical composition & Corn & Tamani guinea grass \\
\hline $\mathrm{DM}\left(\mathrm{g} \mathrm{kg}^{-1} \mathrm{DM}\right)$ & 329.5 & 286.8 \\
\hline $\mathrm{CP}\left(\mathrm{g} \mathrm{kg}^{-1} \mathrm{DM}\right)$ & 85.3 & 165.9 \\
\hline $\mathrm{NDF}\left(\mathrm{g} \mathrm{kg}^{-1} \mathrm{DM}\right)$ & 592.3 & 587.8 \\
\hline $\mathrm{ADF}\left(\mathrm{g} \mathrm{kg}^{-1} \mathrm{DM}\right)$ & 345.9 & 351.6 \\
\hline $\operatorname{Ash}\left(\mathrm{g} \mathrm{kg}^{-1} \mathrm{DM}\right)$ & 43.4 & 76.5 \\
\hline $\mathrm{EE}\left(\mathrm{g} \mathrm{kg}^{-1} \mathrm{DM}\right)$ & 44.7 & 18.3 \\
\hline Lignin $\left(\mathrm{g} \mathrm{kg}^{-1} \mathrm{DM}\right)$ & 28.6 & 24.3 \\
\hline IVDMD ( $\left.\mathrm{g} \mathrm{kg}^{-1} \mathrm{DM}\right)$ & 684.5 & 702.3 \\
\hline $\mathrm{TDN}\left(\mathrm{g} \mathrm{kg}^{-1} \mathrm{DM}\right)$ & 697.1 & 606.4 \\
\hline Fraction A $(\%)$ & 38.78 & 43.24 \\
\hline Fraction B1 (\%) & 22.82 & 25.09 \\
\hline Fraction B2 (\%) & 14.93 & 17.38 \\
\hline Fraction B3 (\%) & 13.70 & 8.04 \\
\hline Fraction C (\%) & 9.76 & 6.25 \\
\hline
\end{tabular}

DM: dry matter; CP: crude protein; NDF: neutral detergent fibre; ADF: acid detergent fibre; EE: ether extract; IVDMD: in vitro dry matter digestibility; and TDN: total digestible nutrients.

Determinations of non-protein nitrogen (NPN), neutral detergent-insoluble nitrogen (NDIN) and acid detergent-insoluble nitrogen (ADIN) were performed according to the methodology described by Licitra, Hernandez and Van Soest (1996), while soluble nitrogen (SN) was estimated according to Krishnmoorthy, Sniffen, Stern and Van Soest (1983).

Protein fractionation was calculated by the CNCPS system (Sniffen, O'Connor, Van Soest, Fox \& Russell, 1992). Protein was analysed and calculated in five fractions: A, B1, B2, B3 and C.
Fraction A, consisting of non-protein nitrogen (NPN), was determined by the difference between total nitrogen (total $\mathrm{N}$ ) and trichloroacetic acidinsoluble N (TCIN). Fraction B1 (soluble fraction, rapidly degraded in the rumen) was obtained by the difference between soluble $\mathrm{N}$ in borate phosphate buffer (BPB) and NPN. Fractions B2 and B3 (insoluble proteins with intermediate and slow ruminal degradation rates, respectively) were determined by the difference between the insoluble BPB fraction and NIDN (fraction B2) and between NDIN and ADIN (fraction B3). Fraction 
$\mathrm{C}$, consisting of rumen insoluble and indigestible proteins, was determined by the residual nitrogen content of the sample after being treated with acid detergent (ADIN) and expressed as a percentage of the total $\mathrm{N}$ of the sample.

The silos were opened after 50 days of fermentation, discarding the silage at the top and bottom of each silo. Samples from the middle of each silo were homogenized and placed in plastic trays. A portion of the fresh silage was separated for analysis of fermentative parameters, such as buffering capacity, $\mathrm{pH}$ and ammonia nitrogen as a percentage of total nitrogen $\left(\mathrm{N}-\mathrm{NH}_{3} / \mathrm{NT}\right)$, following the method described by Bolsen; Lin and Brent, (1992).

Gas and effluent losses and dry matter recovery were determined by the methodology of Jobim, Nussio, Reis and Schmidt (2007). Organic acids (lactic, acetic, propionic and butyric acids) were determined by high-performance liquid chromatography (HPLC) according to the method described by Kung and Shaver (2001).

The other portion of the material (approximately $0.5 \mathrm{~kg}$ ) was weighed and oven-dried at $55^{\circ} \mathrm{C}$ for 72 hours. Then, the samples were ground in mill to pass through a 1-mm sieve and stored in plastic bags for later analysis of the chemical composition and protein fractionation, according to the methodology described above.

Analysis of variance was performed using $\mathrm{R}$ software version R-3.1.1 (2014) and the ExpDes package (Ferreira, Cavalcanti, \& Nogueira, 2014). Regression equations were adjusted, and the respective standard errors were calculated. Graphs were generated using Sigma Plot software.

\section{Results and Discussion}

\section{Fermentative characteristics}

The inclusion of levels of Tamani guinea grass in corn silage affected $(\mathrm{p}<0.05)$ the $\mathrm{pH}$, titratable acidity, buffering capacity, dry matter content, effluent loss, concentrations of lactic and acetic acid. However, there was no significant difference ( $>0.05$ ) among silages for gas production, dry matter recovery, $\mathrm{N}-\mathrm{NH}_{3}$, concentration of propionic and butyric acid.

Figure 1a shows a linear increase in silage $\mathrm{pH}$ with increasing levels of Tamani guinea grass in the ensiled mass. This increase in $\mathrm{pH}$ with the addition of Tamani guinea grass is associated with its increased buffering capacity due to the substantial amount of buffering substances (Figure 1), hindering a fast decrease in $\mathrm{pH}$. However, it is worth mentioning that even with increased $\mathrm{pH}$ levels with the addition of Tamani guinea grass, the final $\mathrm{pH}$ was within the adequate range of 3.8 - 4.2 (Mcdonald; Henderson, \& Heron, 1991), in which the activity of plant proteolytic enzymes, enterobacteria and clostridia are limited.

Buffering capacity showed a quadratic increase with increasing levels of Tamani guinea grass in corn silage (Figure 1b), reaching its maximum point (15.43 eq.mg $\mathrm{HCl} / 100 \mathrm{~g} \mathrm{DM}$ ) at the level of $42.6 \%$ Tamani guinea grass. However, the buffering capacity values were within the optimal range, which is below 20 eq.mg $\mathrm{HCl} / 100 \mathrm{~g} \mathrm{DM}$ (Ferrari \& Lavezzo, 2001), showing that Tamani guinea grass did not hinder the rapid decrease in pH. McDonald et al. (1991) reported that $\mathrm{pH}$ alone cannot be considered a reliable characteristic for the evaluation of bacterial and enzymatic inhibition in plants, which also depends on the level of humidity in the environment, ionic concentration and rate of decline.

Figure 1c shows a linear decrease in DM content with increasing levels of Tamani guinea grass in corn silage. This result is explained by the increased DM content of Tamani guinea grass at harvesting (286.8 $\mathrm{g} \mathrm{kg}^{-1} \mathrm{DM}$ ) compared to that of corn (329.5 $\left.\mathrm{g} \mathrm{kg}^{-1} \mathrm{DM}\right)$. This result corroborates McDonald et al. (1991), which indicated that the DM content in the ensiled mass should be $260-380 \mathrm{~g} \mathrm{~kg}^{-1}$ since 
silages with high DM contents at ensiling can make compaction difficult. The DM content is positively correlated with feed intake and is one of the main factors that affect fermentation during the ensiling process and, consequently, the quality of the silage produced.

Effluent losses were increased due to the reduction in DM content with increasing levels of

(a)

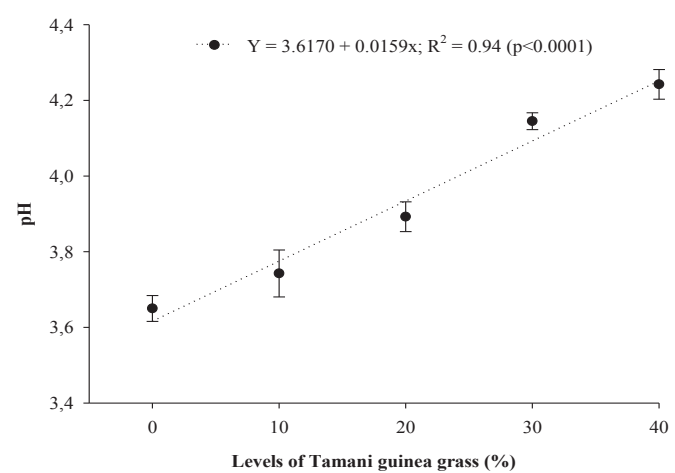

(c)

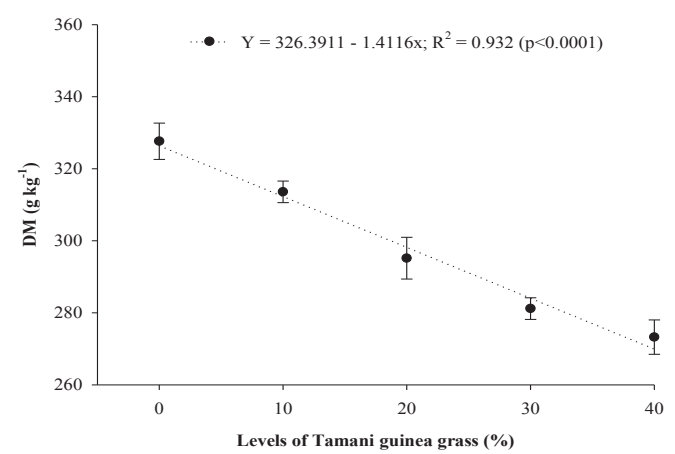

(e)

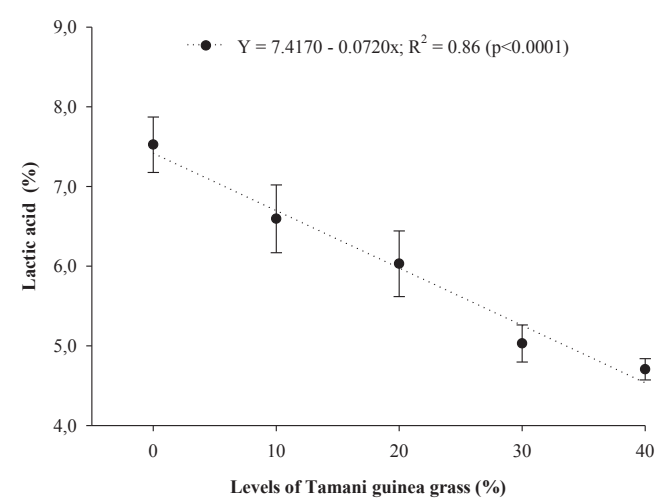

Tamani guinea grass in corn silage (Figure 1d). L. B. Oliveira et al. (2010) reported that the volume of effluent produced in a silo is influenced by mainly the DM content of the ensiled forage; thus, higher effluent losses with increasing levels of Tamani guinea grass are associated with the lower DM content of this forage species.

(b)

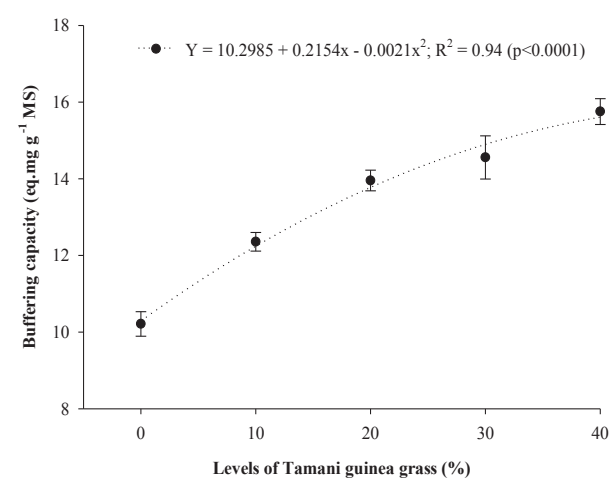

(d)

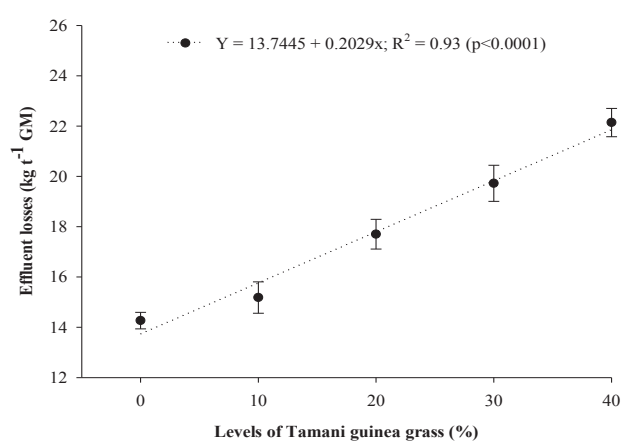

(f)

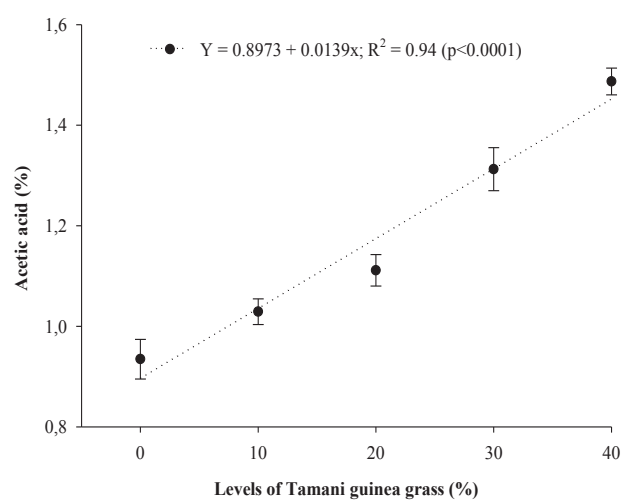

Figure 1. Fermentative characteristics of corn silage with levels of Tamani guinea grass.

Vertical bars represent the standard deviation of the mean. 
The inclusion of levels of Tamani guinea grass in corn silage did not affect the $\mathrm{N}_{-} \mathrm{NH}_{3}$ content of silages. The average concentration of $\mathrm{N}^{-\mathrm{NH}_{3}}$ was $43.54 \mathrm{~g} \mathrm{~kg}^{-1}$, which is considered within the ideal range. According to Kung and Shaver (2001), silages should have less than $100 \mathrm{~g} \mathrm{~kg}^{-1} \mathrm{~N}-\mathrm{NH}_{3}$ to ensure adequate lactic fermentation, reduce proteolysis and inhibit the growth of undesirable microorganisms. Therefore, the activity of bacteria of the genus Clostridium was low, even with the addition of Tamani guinea grass in corn silage. Consequently, there was no excessive protein degradation during ensiling, thus not compromising the nutritional value of the silage.

Figure 1e shows a linear reduction in lactic acid concentration with increasing levels of Tamani guinea grass in corn silage, demonstrating that the highest inclusion of grass $(40 \%)$ resulted in the lowest lactic acid concentration (4.71\%) compared to that for corn only silage (7.52\%). According to Kung and Shaver (2001), good-quality grass silages should have lactic acid levels between 4-6\%; therefore, the inclusion of Tamani guinea grass, even at high levels, did not impair proper fermentation of silage. In a study conducted by Basso et al. (2012), the lactic acid concentration in corn silage was $4.07 \%$, which is lower than the result of the present study.

Lactic acid is an indicator of silage quality and should remain at a higher concentration than those of the other organic acids (acetic, propionic, and butyric acids). All acids produced during the fermentation process contribute to reducing the silage $\mathrm{pH}$, but lactic acid plays a fundamental role in this process since it has a higher dissociation constant than the other acids (Kung \& Ranjit, 2001).

For the acetic acid concentration (Figure 1f), there was a linear increase with the increase in the levels of tamani grass in the corn silage. The corn silage presented a concentration of $0.93 \%$, while the highest level of addition of tamani grass presented $1.49 \%$ acetic acid. The literature recommends acetic acid values below $2 \%$, thus indicating that the values found in the present study are within the recommended range (Kung \& Shaver, 2001).

\section{Chemical characteristics}

The inclusion of Tamani guinea grass in corn silage affected $(\mathrm{p}<0.05)$ the crude protein, ash, lignin, in vitro dry matter digestibility, ether extract and total digestible nutrients contents of silages. However, there was no significant difference $(p>0.05)$ in NDF or ADF contents.

The crude protein content increased linearly with increasing levels of Tamani guinea grass (Figure 2 a) due to the increased crude protein content of Tamani guinea grass at harvesting (165.9 $\mathrm{g} \mathrm{kg}^{-1}$ $\mathrm{DM})$ compared to that of corn $\left(85.3 \mathrm{~g} \mathrm{~kg}^{-1} \mathrm{DM}\right)$. This result is relevant for improving silage nutritive value. Increasing the crude protein content of the ensiled mass is the main advantage of mixed silage production since corn silage is a high-energy feed source that has lower crude protein content than tropical forages.

In studies analysing corn, sorghum, sunflower and millet silages containing tropical forages, Leonel et al. (2009), Cruvinel et al. (2017) and R. R. G. F. Costa et al. (2018) reported an increase in crude protein contents with intercropping and inclusion of forage species at ensiling, demonstrating the benefits of these strategies for silage production.

Ash content showed a quadratic increase with increasing levels of Tamani guinea grass in corn silage (Figure 2b). This result is explained by the increased ash content of Tamani guinea grass (76.5 $\left.\mathrm{g} \mathrm{kg}^{-1} \mathrm{DM}\right)$ compared to that of corn $\left(43.4 \mathrm{~g} \mathrm{~kg}^{-1}\right.$ $\mathrm{DM})$ since tropical forages contain more minerals (Perim et al., 2014a). According to Ashbell (1995), the higher the ash content is, the greater the losses due to inadequate fermentation.

According to Paula et al. (2016), grass silage has a higher value of ash compared to corn silage 
due to the genetic capacity of forages to accumulate minerals, while older plants have low accumulation capacity.

The NDF and ADF contents of the silages were not affected $(p>0.05)$ by the addition of Tamani guinea grass to corn silage. Therefore,

(a)

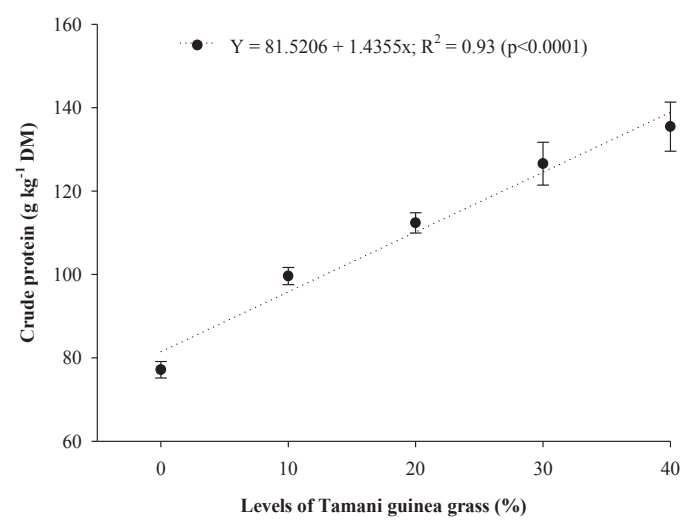

(c)

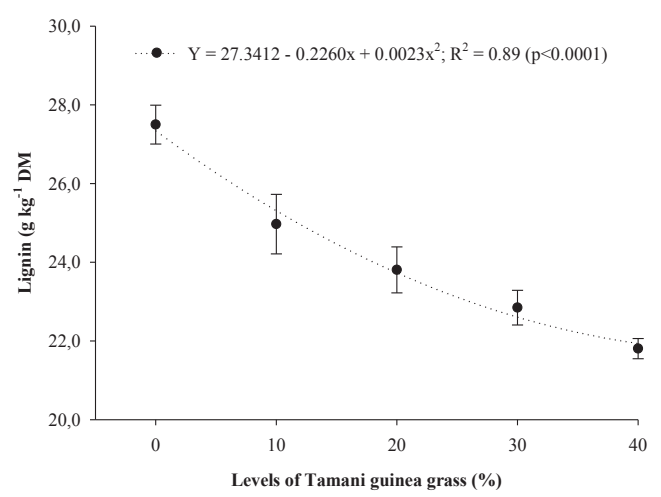

(d)

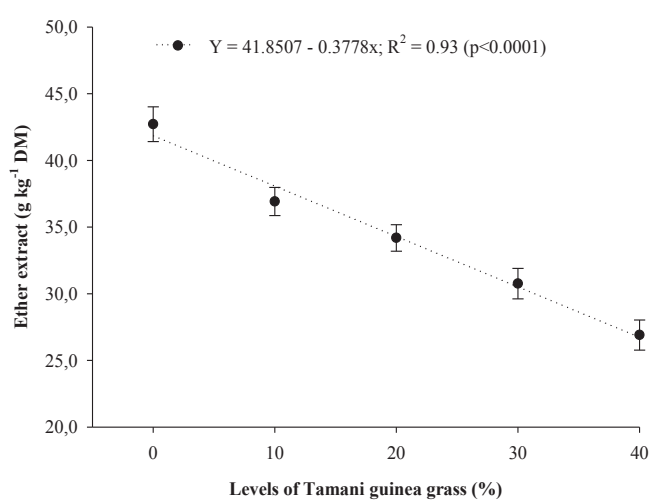

the composition of these fibrous fractions was not changed. The lack of statistical significance may be associated with the similar NDF and ADF contents of both crops at harvesting (Table 1), averaging $598.6 \mathrm{~g} \mathrm{~kg}^{-1}$ and $363.7 \mathrm{~g} \mathrm{~kg}^{-1}$ DM NDF and ADF in the silage, respectively. (b)

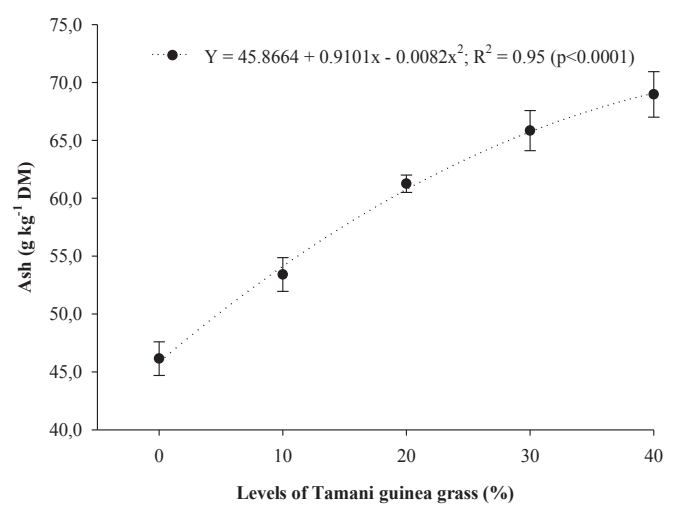

(d)

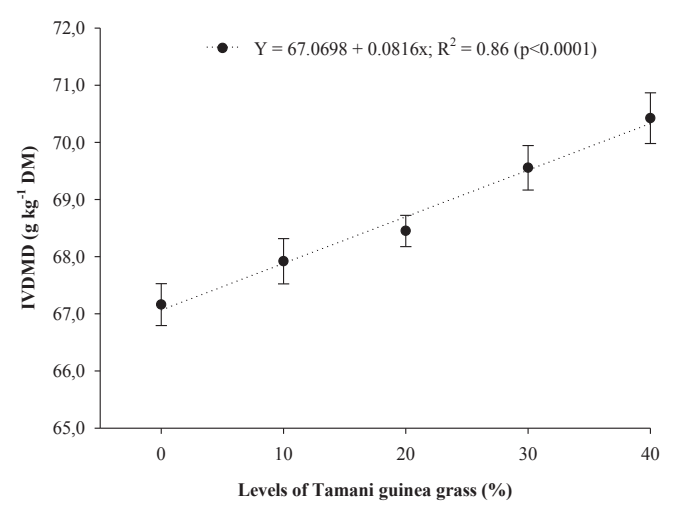

(e)

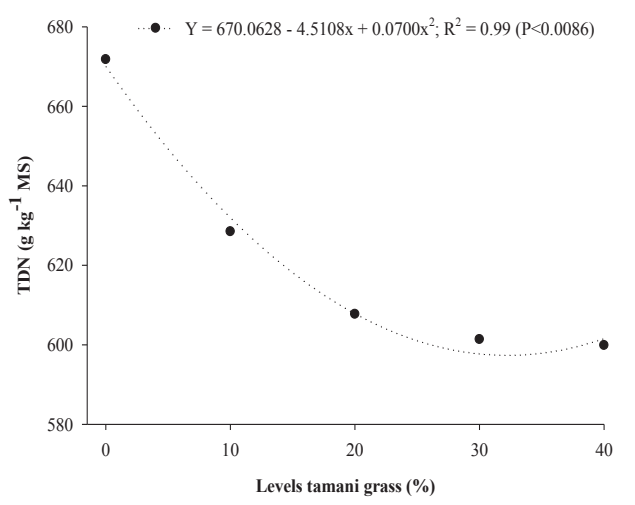

Figure 2. Chemical characteristics of corn silage with levels of Tamani guinea grass. Vertical bars represent the standard deviation of the mean. 
NDF values above $600 \mathrm{~g} \mathrm{~kg}^{-1}$ DM may impair feed digestibility because high levels of NDF are associated with reduced dry matter intake due to the rumen fill effect. Therefore, feed intake can be limited by the consumption of large amounts of fibrous feeds, thus reducing the rate of passage through the digestive tract (Bosa et al., 2012).

The dietary energy content can be estimated using fibrous components; thus, it is essential to determine the fibre contents in feeds (Khan et al., 2015). Low levels of ADF are indicative of an enhanced nutritional value in silages because this parameter has a negative correlation with digestibility. Thus, the lower the ADF content is, the better the feed DM digestibility (Van Soest, 1994).

Lignin levels showed a quadratic increase with increasing levels of Tamani guinea grass in corn silage (Figure 2c) due to the reduced lignin content of Tamani guinea grass compared to that of corn crop at harvesting (Table 1), where fibre dilution occurred. Tamani guinea grass has a high leaf:stem ratio, leading to less fibrous fractions (Mendonça et al., 2017).

Plants with high lignin content are considered low-quality forage sources for livestock because lignin is an indigestible amorphous polymer containing phenylpropanoid units present in the cell wall (structural function); therefore, it prevents the utilization of nutrients by animals, thereby reducing their performance (Maranhão, Silva, Bonomo, \& Pires, 2009).

In contrast to lignin content, IVDMD increased linearly with increasing levels of Tamani guinea grass in corn silage (Figure 2d). Although corn has a higher content of non-structural carbohydrates (starch, pectin and sugars), which are usually more digestible than structural carbohydrates (Van Soest, 1994), the IVDMD increased $4.1 \%$ with the addition of Tamani guinea grass at the level of $40 \%$. Although the increase was small, it is important to highlight the benefits of using mixed silages. The inclusion of Tamani guinea grass resulted in increased crude protein and IVDMD levels and decreased lignin content; therefore, it may be an effective alternative to increase the quality of corn only silage.

A study by N. R. Costa et al. (2017) compared exclusive corn silage with corn silage intercropped with Brachiaria brizantha cv. Marandu and did not find a significant difference in the lignin content; however, the digestibility content was higher in the intercropped silage, thus making the intercropped silage with grass a higher quality food.

The average IVDMD in corn silage was 676.6 ( $\mathrm{g} \mathrm{kg}^{-1} \mathrm{DM}$ ), which is higher than that reported by Marquardt, Jobim, Bueno and Ribeiro (2017) of $635.5\left(\mathrm{~g} \mathrm{~kg}^{-1} \mathrm{DM}\right)$ in corn silage harvested at different heights.

For the contents of ether extract and total digestible nutrients, there was a linear and quadratic reduction, respectively, with the addition of tamani grass (Figure 2e, f). This result is associated with the reduced fat content of tropical forages (Table 1) compared with that of corn crops, which may compromise the amount of total digestible nutrients (TDN). According to Marafon et al. (2015), the nutritional value of the silage is determined by its quality, and corn silage is considered a good-quality feed source due to its high amount of energy content from grain starch (Perim et al., 2014a).

The ether extract refers to the amount of oil present in the feed, and an increased amount of oil is advantageous because it contains more energy than protein. Thus, silages with high levels of ether extract allow satiety and higher gains than silages with low levels of ether extract (Ferreira, Andreotti. Pascoaloto, Costa, \& Augusto, 2017).

\section{Protein fractionation}

The inclusion of levels of Tamani guinea grass in corn silage also affected $(p<0.05)$ the protein fractionation (A, B1, B2, B3 and C). Protein fraction A showed a quadratic increase with increasing levels of Tamani guinea grass in corn silage (Figure 
3a), demonstrating the positive effects of this forage on the ruminal degradation rate, due to the higher levels of protein and lower levels of lignin (Table 1) with better structural arrangement of the cell wall.

(a)

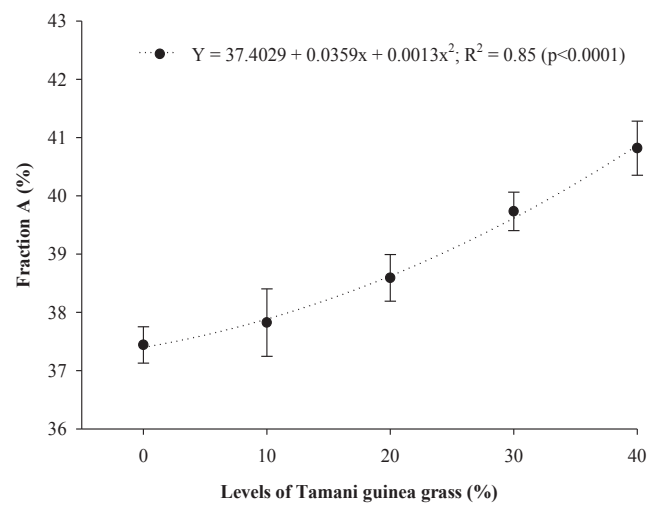

(c)

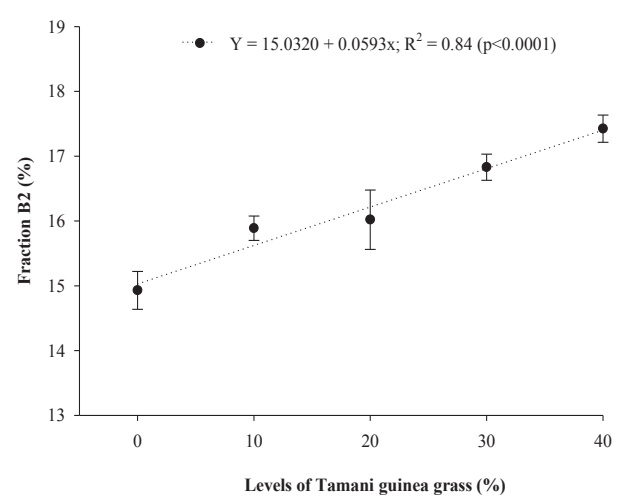

(b)

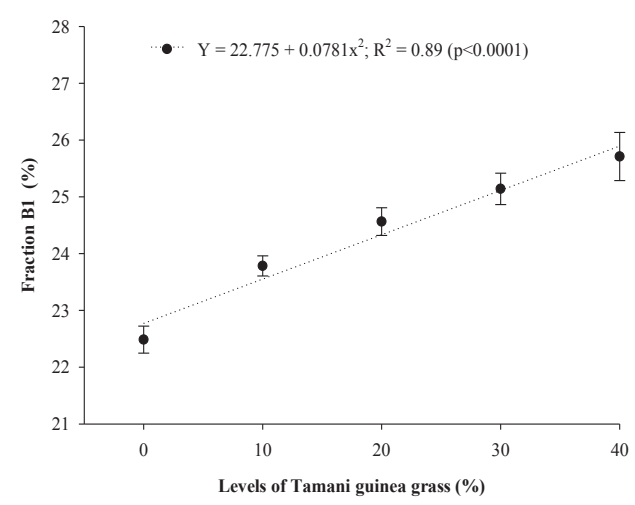

(d)



(e)

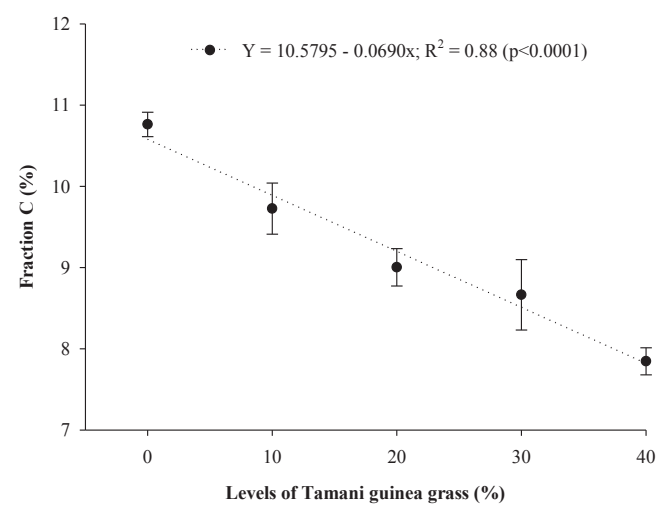

Figure 3. Protein fractionation of corn silage with levels of Tamani guinea grass. Vertical bars represent the standard deviation of the mean. 
Fraction A, previously classified as non-protein nitrogen, was reclassified as ammonia to better predict the contribution of metabolizable protein from free amino acids and small peptides in the rumen (Higgs, Chase, Ross, \& Van Amburgh, 2015). It is essential for the proper functioning of the rumen since ruminal microorganisms use the fermentation products of fraction A as a nitrogen source (Russell, O'connor, Fox, Van Soest, \& Sniffen, 1992).

High proportions of non-protein nitrogen may contribute to increased nitrogen losses due to the lack of readily available carbon substrate for the synthesis of microbial protein. Therefore, an adequate carbohydrate-protein balance is essential for the health of ruminal microorganisms (Queiroz et al., 2011).

Protein fraction B1 increased linearly with increasing levels of Tamani guinea grass in corn silage (Figure 3b), i.e., an increase of $14.31 \%$ compared to that in corn only silage. This result indicates that the addition of Tamani guinea grass to corn silage increased the solubility and ruminal degradation of fraction B1 since it is a soluble fraction that undergoes rapid ruminal degradation (Sniffen et al., 1992). Thus, the addition of Tamani guinea grass to silages can significantly change their protein content, leading to better feed utilization and, consequently, better animal performance. This result can be attributed to the morphological characteristics of Tamani guinea grass, which is a small forage with short stems and a high leaf:stem ratio (Machado, Cecato, Comunello, Cocenço, \& Ceccon, 2017).

Neumann, Nornberg, Leão, Horst and Figueira, (2017) reported a value of $7.01 \%$ fraction B1 in corn silage, which is lower than the value obtained in this study for corn only silage.

Figure $3 \mathrm{c}$ shows a linear increase in protein fraction B2 with the addition of Tamani guinea grass, with a maximum increase of $16.67 \%$ compared to that in corn only silage. This result is relevant for improving the quality of corn silage; despite its high energy content (Perim et al., 2014b), corn silage has lower protein content (Table 1) when compared with Tamani guinea grass. Fraction B2 has a moderate ruminal degradation rate, but fractions $\mathrm{B} 1+\mathrm{B} 2$ are characterized by faster rumen degradation rates than fraction B3, thus contributing to microbial nitrogen supply (Sniffen et al., 1992).

Protein fraction B3 decreased linearly with increasing levels of Tamani guinea grass in corn silage (Figure 3d) due to the more favourable spatial arrangement of its cell wall components, with lower lignin contents than corn only silage (Table 1). Corn only silage had a total of $14.40 \%$ fraction B3, while the silage containing $40 \%$ Tamani guinea grass had a value of $9.21 \%$ fraction $\mathrm{B} 3$.

Cattle usually select forage leaves with a high proportion of fractions A, B1, B2 and B3 (Branco et al., 2012), demonstrating the positive influence of Tamani guinea grass on mixed silage production due to its high proportion of leaves with high nutritional value (Machado et al., 2017).

Protein fraction $\mathrm{C}$ (Figure $3 \mathrm{e}$ ) responded to treatments similarly to fraction $\mathrm{B} 3$. The content of fraction C was 37.07\% lower in the silage containing the highest level of Tamani guinea grass than in corn only silage (10.76\%). Fraction $\mathrm{C}$ is indigestible to animals since it is insoluble in neutral and acid detergents (Sniffen et al., 1992). Thus, the use of Tamani guinea grass during corn ensiling is a good option in terms of nutrition since its inclusion increased the protein value and decreased the fibrous fraction of feed. Velásquez et al. (2010) reported that fraction $C$ has lignin-bound proteins and nitrogen compounds that are resistant to degradation by microbial enzymes. Viana et al. (2012) reported that corn silage had a total of $14.10 \%$ fraction $\mathrm{C}$, which is higher than the results of the present study (10.57\%). 


\section{Conclusion}

The addition of Tamani guinea grass in corn silage increased the $\mathrm{pH}$ and buffering capacity and reduced the dry matter content and lactic acid concentration. However, it did not affect the fermentative characteristics of the silages.

The addition of Tamani guinea grass in corn silage at the level of $40 \%$ led to higher crude protein, in vitro dry matter digestibility, and proteins $\mathrm{A}, \mathrm{B} 1$ and $\mathrm{C}$ and decreased the fractions $\mathrm{B} 3$ and $\mathrm{C}$, which makes Tamani guinea grass an alternative to improve the quality of exclusive corn silage, resulting in better quality silage.

\section{Acknowledgments}

The authors would like to thank the Instituto Federal Goiano for financially supporting this study.

\section{References}

Ashbell, G. (1995). Basic principles of preservation of forage, by-products and residues as silage or hay. Bet Dagan: Agricultural Research Organization, The Volcani Centeer.

Basso, F. C., Lara, E. C., Assis, F. B., Rabelo, C. H. S., Morelli, M., \& Reis, R. A. (2012). Características da fermentação e estabilidade aeróbia de silagens de milho inoculadas com Bacillus subtilis. Revista Brasileira de Saúde e Produção Animal, 13(4), 10091019. doi: 10.1590/S1519-99402012000400003

Bolsen, K. K., Lin, C., \& Brent, B. E. (1992). Effect of silage additives on the microbial succession and fermentation process of alfalfa and corn silages. Journal Dairy Science, 75(11), 3066-3083. doi: 10. 3168/jds.S0022-0302(92)78070-9

Bosa, R., Faturi, C., Vasconcelos, H. G. R., Cardoso, A. M., Ramos, A. F. O. E., \& Azevedo, J. C. (2012). Consumo e digestibilidade aparente de dietas com diferentes níveis de inclusão de torta de coco para alimentação de ovinos. Acta Scientiarum. Animal Sciences, 34(1), 57-62. doi: 10.4025/actascianimsci. v34i1.11936

Branco, A. F., Viana, K. B., Castañeda, R. D., Prohmann, P. E., Coneglian, S. M., \& Mouro, G. F. (2012). Chemical composition and crude protein fractions of Coastcross grass under grazing on winter, spring and summer in Southern Brazil. Acta Scientiarum. Animal Sciences, 34(2), 183-187. doi: 10.4025/ actascianimsci.v34i2.10895

Brandstetter, E. V., Costa, K. A. P., Santos, D. C., Souza, W. F., Silva, V. C., \& Dias, M. B. C. (2019). Protein and carbohydrate fractionation of Jiggs Bermuda grass in different seasons and under intermittent grazing by Holstein cows. Acta Scientiarum. Animal Sciences, 41, e-43363, 1-7. doi: 10. 4025/ actascianimsci.v41i1.43363

Chandler, P. (1990). Energy prediction of feeds by forage testing explorer. Feedstuffs, 62(36), 12.

Costa, K. A. P., Assis, R. L., Guimarães, K. C., Severiano, E. C., Assis, J. M., Neto, Crunivel, W. S.,... Santos, N. F. (2011). Silage quality of Brachiaria brizantha cultivars ensiled with different levels of millet meal. Arquivo Brasileiro de Medicina Veterinária e Zootecnia, 63(1), 188-195. doi: 10.1590/ S010209352011000100028

Costa, N. R., Andreotti, M., Crusciol, C. A. C., Lima, C. G. R., Castilhos, A. M., Souza, D. M. de,... Pariz, C. M. (2017). Yield and nutritive value of the silage of corn intercropped with tropical perennial grasses. Pesquisa Agropecuária Brasileira, 52(1), 63-73. doi: 10.1590/S0100-204X2017000100008

Costa, R. R. G. F., Costa, K. A. P., Souza, W. F., Epifanio, P. S., Santos, C. B., Silva, J. T., \& Oliveira, S. S. (2018). Production and quality of silages pearl millet and Paiaguas palisadegrass in monocropping and intercropping in different forage systems. Bioscience Journal, 34(2), 957-967, doi: 10.14393/BJ-v34n2 a2018-33843

Cruvinel, W. S., Costa, K. A. P., Teixeira, D. A. A., Silva, J. T. da, Epifanio, P. S., Costa, P. H. C. P., \& Fernandes, P. B. (2017). Fermentation profile and nutritional value of sunflower silage with Urochloa brizantha cultivars in the off-season. Revista Brasileira de Saúde e Produção Animal, 18(2), 249259. doi: 10.1590/s1519-99402017000200004

Epifanio, P. S., Costa, K. A. P., Severiano, E. C., Cruvinel, W. S., Bento, J. C., \& Perim, R. C. (2014). Fermentative and bromatological characteristics of Piata palisadegrass ensiled with levels of meals from biodiesel industry. Semina. Ciências Agrárias, 35(1), 491-504. doi: 10.5433/1679-0359.2014v35n1p491

Ferrari, E., Jr., \& Lavezzo, W. (2001). Qualidade da silagem de capim-elefante (Pennisetum purpureum Schum.) emurchecido ou acrescido de farelo de mandioca. Revista Brasileira de Zootecnia, 30(5), 1424-1431. doi: 10.1590/S1516-35982001000600006 
Ferreira, E. B., Cavalcanti, P. P., \& Nogueira, D. A. (2014). ExpDes: an R package for ANOVA and experimental designs. Applied Mathematics, 5, 2952-2958. doi: 10.4236/am.2014.519280

Ferreira, J. P., Andreotti, M., Pascoaloto, I. M., Costa, N. R., \& Augusto, J. G. (2017). Influência de espaçamentos e consórcios na qualidade bromatológica de silagem de milho. Revista Espacios, 38(46), 16. doi: 10.17523/bia.v74n3p237

Higgs, R. J., Chase, L. E., Ross, D. A., \& Van Amburgh, M. E. (2015). Updating the Cornell Net Carbohydrate and Protein System feed library and analyzing model sensitivity to feed inputs. Journal of Dairy Science, 98(9), 6340-6360. doi: 10.3168/jds.2015-9379

Jobim, C. C., Nussio, L. G., Reis, R. A., \& Schmidt, P. (2007). Avanços metodológicos na avaliação da qualidade da forragem conservada. Revista Brasileira de Zootecnia, 36(suppl), 101-119. doi: 10.1590/ S1516-35982007001000013

Khan, N. A., Tewoldebrhan, T. A., Zom, R. L. G., Cone, J. W., \& Hendriks, W. H. (2012). Effect of corn silage harvest maturity and concentrate type on milk fatty acid composition of dairy cows. Journal Dairy Science, 95(3), 1472-1483. doi: 10.3168/jds.20114701

Khan, N. A., Yu, P., Ali, M., Cone, J. W., \& Hendriks, W. H. (2015). Nutritive value of maize silage in relation to dairy cow performance and milk quality. Journal Science Food Agriculture, 95(2), 238-252. doi: $10.1002 /$ jsfa. 6703

Krishnmoorthy, U., Sniffen, C. J., Stern, M. D., \& Van Soest, P. J. (1983). Evaluation of a mathematical model of rumen digestion and an in vitro simulation of rumen proteolysis to estimate the rumenundegraded nitrogen content of feedstuffs. British Journal of Nutrition, 50(2), 555-568. doi: 10.1079/ BJN19830127

Kung, L., Jr., \& Ranjit, N. K. (2001). The effect of Lactobacillus buchneri and other additives on the fermentation and aerobic stability of barley silage. Journal of Dairy Science, 84(5), 1149-1155. doi: 10. 3168/jds.S0022-0302(01)74575-4

Kung, L., Jr., \& Shaver, R. (2001). Interpretation and use of silage fermentation analysis reports. Focus on Forage, 3(13), 1-5.

Leonel, F. P., Pereira, J. C., Costa, M. G., Marco, P., Jr., Silva, C. J., \& Lara, L. A. (2009). Consórcio capimbraquiária e milho: comportamento produtivo das culturas e características nutricionais e qualitativas das silagens. Revista Brasileira de Zootecnia, 38(1), 166-176. doi: 10.1590/S1516-35982009000100021
Licitra, G., Hernandez, T. M., \& Van Soest, P. J. (1996). Standardization of procedures for nitrogen fractionation of ruminant feeds. Animal Feed Science and Technology, 57(4), 347-358. doi: 10.1016/03778401(95)00837-3

Machado, L. A. Z., Cecato, U., Comunello, E., Cocenço, G., \& Ceccon, G. (2017). Estabelecimento de forrageiras perenes em consórcio com soja, para sistemas integrados de produção agropecuária. Pesquisa Agropecuária Brasileira, 52(7), 521-529. doi: 10.1590/s0100-204x2017000700006

Marafon, F., Neumann, M., Carletto, R., Wrobel, F. L., Mendes, E. D., Spada, C. A., \& Faria, M. V. (2015). Características nutricionais e perdas no processo fermentativo de silagens de milho, colhidas em diferentes estádios reprodutivos com diferentes processamentos de grãos. Semina: Ciências Agrárias, 36(2), 917-93. doi: 10.5433/1679-0359.2015v36n2p917

Maranhão, C. M. A., Silva, C. C. F., Bonomo, P., \& Pires, A. J. V. (2009). Produção e composição químicobromatológica de duas cultivares de Braquiária adubadas com nitrogênio e sua relação com o índice SPAD. Acta Scientiarum. Animal Sciences, 31(2), 117-122. doi: 10.4025/actascianimsci.v31i2.4305

Marquardt, F. I., Jobim, C. C., Bueno. A. V. I., \& Ribeiro, M. G. (2017). Altura de corte e adição de inoculante enzimo-bacteriano na composição químicobromatológica e digestibilidade de silagens de milho avaliada em ovinos. Ciência Animal Brasileira, 18(1), 1-9. doi: 10.1590/1089-6891v18e-42888

Mcdonald, P., Henderson, N., \& Heron, S. (1991). The biochemistry of silage. Marlow Bucks: Chalcombe Publications.

Mendonça, C. H. A., Lima, V. M. M., Trindade, J. S., Castro, J. N., Moreira, J. A., Vilela, R. A., \& Melo, T. L. (2017). Avaliação do híbrido BRS Tamani submetido a diferentes doses de nitrogênio. Revista Eletrônica Interdisciplinar, 1(17), 1-17.

Mertens, D. R. (2002). Gravimetric determination of amylase-treated neutral detergent fiber in feeds with refluxing in beaker or crucibles: collaborative study. Journal of AOAC International, 85(6), 1217-1240. doi: 10.1093/jaoac/85.6.1217

Neumann, M., Nornberg, J. L., Leão, G. F. M., Horst, E. H., \& Figueira, D. N. (2017). Chemical fractionation of carbohydrate and protein composition of corn silages fertilized with increasing doses of nitrogen. Ciência Rural, 47(5) ed20160270. doi: $10.1590 / 0103-8478 \mathrm{cr} 20160270$ 
Official Methods of Analysis (1990). Agricultural Chemicals; Contaminants; Drugs (15nd ed.). Arlington, VA: Association Official Analytical Chemists.

Oliveira, L. B., Pires, A. J. V., Carvalho, G. G. P., Ribeiro, L. S. O., Almeida, V. V., \& Peixoto, C. A. M. (2010). Perdas e valor nutritivo de silagens de milho, sorgosudão, sorgo forrageiro e girassol. Revista Brasileira de Zootecnia, 39(1), 61-67. doi: 10.1590/S151635982010000100008

Oliveira, S. S., Costa, K. A. P., Souza, W. F., Santos, C. B., Teixeira, D. A. A., \& Silva, V. C. (2020). Production and quality of the silage of sorghum intercropped with Paiaguas palisadegrass in different forage systems and at different maturity stages. Animal Production Science, 60(4), 1-11. doi: 10.1071/ AN17082

Pariz, C. M., Costa, C., Crusciol, C. A. C., Meirelles, P. R. L., Castilhos, A. M., Andreotti, M.,... Martello, J. M. (2017). Silage production of corn intercropped with tropical forages in an integrated crop-livestock system with lambs. Pesquisa Agropecuária Brasileira, 52(1), 54-62. doi: 10.1590/s0100$204 \times 2017000100007$

Paula, F. L. M., Menezes, L. F. G., Paris, W., Ronsani, R., Hoppen, S. M., \& Ciesca, J. (2016). Produção de silagem e composição química do consórcio de milho e capim-Tanzânia. Semina: Ciências Agrárias, 37(3), 1607-1616. doi: 10.5433/1679-0359.2016v37 n3p1607

Perim, R. C., Costa, K. A. P., Epifanio, P. S., Souza, W. F., Francischini, R., Teixeira, D. A. A.,... Santos, J. R. D. R. (2014a) Fermentative and bromatological characteristics of Piata Palisade grass ensiled with energetic brans. American Journal of Plant Sciences, 5(7), 942-954. doi: 10.4236/ajps.2014.57107

Perim, R. C., Costa, K. A. P., Epifanio, P. S., Teixeira, D. A. A., Fernandes, P. B., \& Santos, D. R., Jr. (2014b). Protein and carbohydrate fractionation of Piata palisadegrass ensiled with energetic meals. Acta Scientiarum. Animal Sciences, 36(2), 193-200. doi: 10.4025/actascianimsci.v36i2.22046

Queiroz, M. F. S., Berchielli, T. T., Morais, J. A. S., Messana, J. D., Malheiros, E. B., \& Ruggieri, A. C. (2011). Digestibilidade e parâmetros ruminais de bovinos consumindo Brachiaria brizanta cv. Marandu. Archivos de Zootecnia, 60(232), 9971008. doi: 10.4321/S0004-05922011000400016

R Software version R-3.1.1 (2014). A language and environment for statistical computing. R Foundation for Statistical Computing, Vienna, Austria. ISBN 3-900051-07-0, URL http://www.R-project.org.
Ribeiro, M. G., Costa, K. A. P., Souza, W. F., Cruvinel, W. S., Silva, J. T., \& Santos, D. R., Jr. (2017). Silage quality of sorghum and Urochloa brizantha cultivars monocropped orinter cropped in different planting systems. Acta Scientiarum. Animal Sciences, 39(3), 243-250. doi: 10.4025/actascianimsci. v39i3.33455

Russell, B. J., O'connor, J. D., Fox, D. J., Soest, P. J. V., \& Sniffen, C. J. (1992). A net carbohydrate and protein system for evaluation cattle diets: ruminal fermentation. Journal Dairy Science, 70(11), 35513581. doi: $10.2527 / 1992.70113551 x$

Santos, A. D., Fonseca, D. M., Sousa, B. M. L., Santos, M. E. R., \& Carvalho, N. A. (2020) Pasture structure and production of supplemented catte in deferred signalgrass pasture. Ciência Animal Brasileira, 21, e43578. doi: 10.1590/1809-6891v21e-43578

Santos, H. G., Jacomine, P. K. T., Anjos, L. H. C., Oliveira, V. A., Lumbreras, J. F., Coelho, M. R.,... Cunha, T. J. F. (2018). Sistema brasileiro de classificação de solos (5a ed.). Brasilia, DF: EMBRAPA Solos.

Sniffen, C. J., O’Connor, D. J., Van Soest, P. J., Fox, D. G., \& Russell, J. B. (1992). A net carbohydrate and protein system for evaluating cattle diets: carbohydrate and protein availability. Journal of Animal Science, 70(11), 3562-3577. doi: 10.2527/1992.70113562x

Souza, W. F., Costa, K. A. P., Guarnieri, A., Severiano, E. C., Silva, J. T., Teixeira, D. A. A.,... Dias, M. B. C. (2019). Production and quality of the silage of corn intercropped with Paiaguas palisadegrass in different forage systems and maturity stages. Revista Brasileira de Zootecnia, 48, e20180222. doi: 10. 1590/rbz4820180222

Tilley, J. M. A., \& Terry, R. A. (1963). A two-stage technique of the "in vitro" digestion of forage crop. Journal of the British Grassland Society, 18(2), 104111. doi: 10.1111/j.1365-2494.1963.tb00335.x

Van Soest, P. J. (1994). Nutritional ecology of the ruminant (2nd ed.). Ithaca: Cornell University Press.

Velásquez, P. A., Berchielli, T. T., Reis, R. A., Rivera, A. R., Dian, P. H. M., \& Teixeira, I. A. M. (2010). Composição química, fracionamento de carboidratos e proteínas e digestibilidade in vitro de forrageiras tropicais em diferentes idades de corte. Revista Brasileira Zootecnia, 39(6), 1206-1213. doi: 10.1590/ S1516-35982010000600007

Viana, P. T., Pires, A. J. V., Oliveira, L. B., Carvalho, G. G. P., Ribeiro, L. S. O., Chagas, D. M. T.,... Carvalho, A. O. (2012). Fracionamento de carboidratos e de proteína das silagens de diferentes forrageiras. Revista Brasileira de Zootecnia, 41(2), 292-297. doi: 10.1590/S1516-35982012000200009 